\title{
Energy supply in buildings: heat pump and micro-cogeneration
}

\author{
Marta Galera Martínez, Laura Cristóbal Andrade, Pastora M. Bello Bugallo*, Manuel Bao \\ Iglesias \\ Department of Chemical Engineering and Seminar of Renewable Energy (Aula de Energías Renovables), \\ University of Santiago de Compostela, Spain \\ *Corresponding author. Tel: +34 881816757, Fax: +34981528050,E-mail: pastora.bello.bugallo@usc.es
}

\begin{abstract}
Heat pumps and micro-cogeneration technology for residential applications are an alternative for energy saving and for improving the energy efficiency. Nowadays, several nomenclatures are used for these technologies, creating confusion within this field. This situation causes that the commercial brands could not offer their products clearly to the market as the concepts and terminology they use are usually incorrect. This paper clarifies these concepts using thermodynamics, and provides clear classification criteria considering the heat pump and the power cycle as the starting point. Therefore, this paper provides an update review of heat pumps and micro-cogeneration which could be of great importance in the future for achieving the goals of the European legislation, especially those related to energy supply in buildings. It emphasizes the principles of operation and the advantages of the different devices as well as the consideration of this technology as renewable energy.
\end{abstract}

Keywords: Energy Efficiency, Heat Pump, Micro-cogeneration, Distributed Generation

\section{Introduction}

Buildings have an impact on long-term energy consumption. According to data from 2010, buildings account for $40 \%$ of the total energy use in the European Union (EU) [1]. Around the same percentage of all greenhouse gas emissions in developed countries have their origin in building equipments, where approximately $60 \%$ are produced by cooling and heating systems [2]. However, the energy use of any residence largely depends on its architectural design. All these factors are included in the Directive 2002/91/EC on the energy performance of buildings [3], which states that the calculation methodology must take into account insulation, technical and installation characteristics, design and positioning in relation to climatic aspects, solar exposure and influence of neighboring structures, own-energy generation and other factors such as indoors climate, which influences the energy demand. Directive 2009/28/CE on the promotion of the use of energy from renewable sources similarly talks about passive energy systems which use building design to harness energy [4]. This directive also requires that, before the end of 2014, Member States enforce the use of minimum levels of energy from renewable sources in buildings. This requirement may be fulfilled through heating and cooling systems that use a significant percentage of renewable energy sources [4].

Heat pumps (HP) and micro-cogeneration technologies for residential applications are an alternative for energy saving and for improving energy efficiency. Consequently, these technologies allow reducing the greenhouse gas emissions and can reduce energy dependence.

This paper clarifies these concepts using thermodynamics, and provides clear classifications considering the HP and the power cycle as the starting point. Therefore, this paper provides an update review of HPs and micro-cogeneration which could be of great importance in the future for achieving the goals of the European legislation. It emphasizes the principles of operation and the advantages of the different devices. 


\section{Heat pumps}

\subsection{Foundations}

$\mathrm{HP}$ is a system that undergoes a thermodynamic cycle while thermally communicating with two bodies located in the surroundings or thermal reservoirs. They are devices designed to utilize low temperature sources of energy to heat a space to higher temperatures. The low temperature source may be the atmospheric air, the ground or a nearby body of water (lake or river). This energy comes from the solar radiation reaching the surface of the earth and its use constitutes therefore an indirect use of solar energy [5]. On the other hand, the space to be heated corresponds to the circuit for space heating, usually water or air. Net work input is needed to be provided by electricity, though it may also be provided by a mechanical engine. The components of a HP cycle, namely vapor compression HP, are: evaporator, condenser, compressor and expansion valve (Fig. 1).

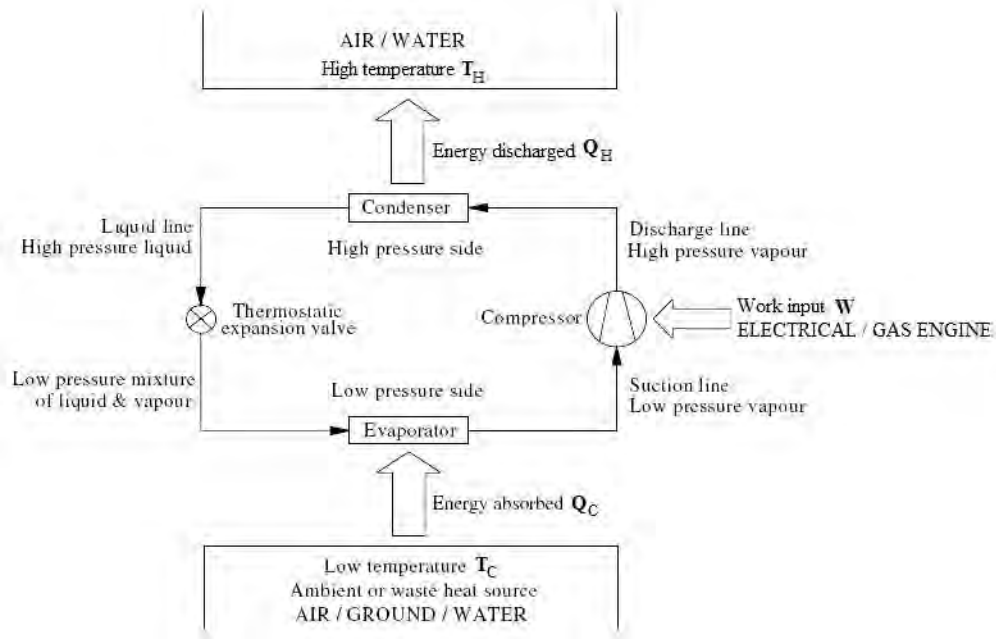

$$
\begin{aligned}
& W=Q_{H}-Q_{C} \\
& C O P=\frac{Q_{H}}{W} \\
& C O P=\frac{Q_{H}}{Q_{H}-Q_{C}} \\
& C O P_{\text {máx }}=\frac{T_{H}}{T_{H}-T_{C}}
\end{aligned}
$$

Fig. 1. Typical HP schematic.

The objective of a HP is to maintain the temperature above that of the surroundings. According to energy flows, the energy balance is defined by Eq. (1). Therefore, the Coefficient of Performance (COP) of a HP is calculated as the amount of energy discharged from the cycle system to the hot reservoir by the net work input needed to accomplish this effect (Eq. (2)). As $\mathrm{Q}_{\mathrm{H}}$ is greater than $\mathrm{Q}_{\mathrm{C}}$, COP is never less than unity but it is also limited to a maximum value. The maximum COP of a reversible HP cycle is obtained in terms of reservoirs temperatures (Eq. (4)). In any case, and in spite of these limitations, it is desirable to obtain high values of COP.

\subsection{Heat pumps classification}

\subsubsection{Thermodynamic cycle type}

The foundations of HPs are used to give a first qualitative classification depending on the thermodynamic cycle. Accordingly, there are mainly three types of HPs (Fig. 2). VaporCompression Heat Pumps (VCHPs) are commonly used for space heating applications. Its compressor is mechanical, so it requires mechanical drive energy. Vapor Absorption Heat Pumps (VAHPs) are also used for space heating and require thermal drive energy. Both systems involve changes in phase, whereas in gas refrigeration systems the working fluid stays as a gas throughout. The Brayton refrigeration cycle illustrates an important type of gas refrigeration system [6] and consequently it can be also worked as a HP [7]. 


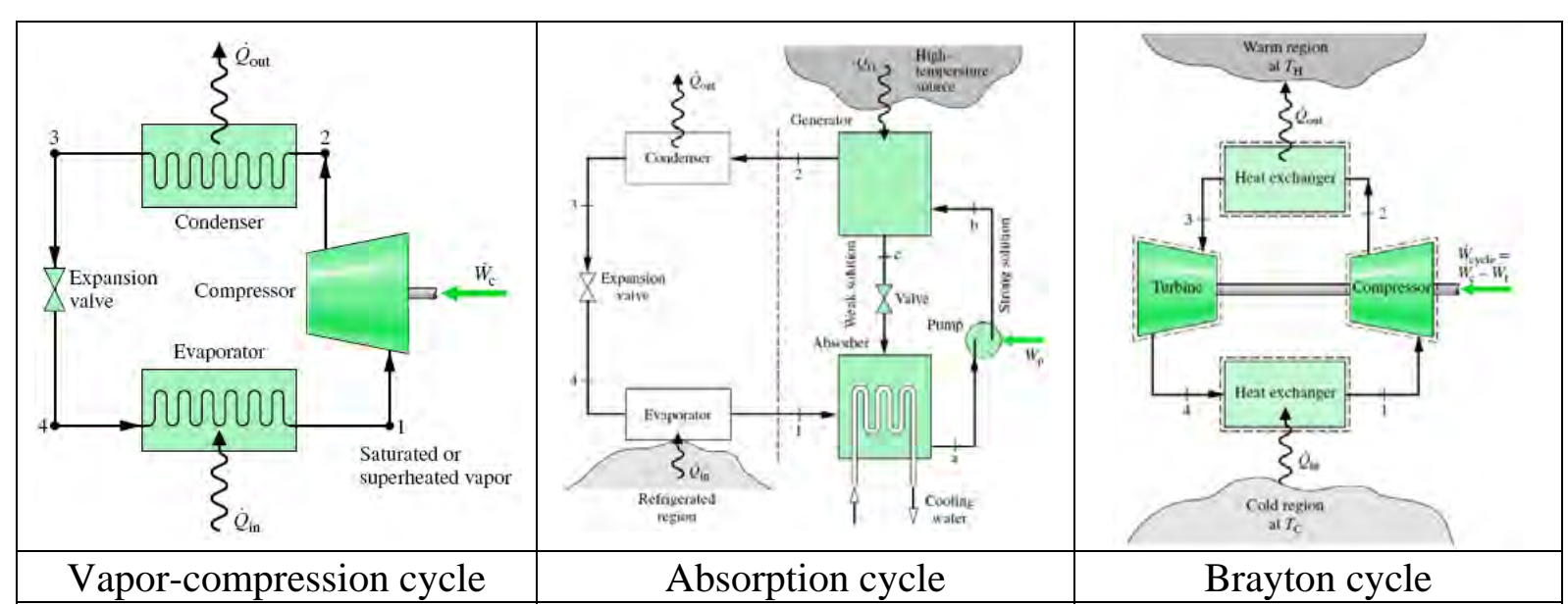

Fig. 2. Diagrams of principal refrigeration or heat pump cycle [6].

\subsubsection{Equipment}

According to Fig. 1, and depending on the type of equipment that the HP uses to operate, different classifications can be considered.

- $\quad$ Evaporator. Depending on the type of equipment used to evaporate the refrigerant fluid, a classification can be made including any type of heat exchanger, as differently disposed shelland-tube heat exchangers, solar collectors, etc. That depends on the cold reservoir. As a particular case, the Solar Assisted Heat Pump (SAHP) system mixes HP and solar technology, using solar radiation as evaporating heat source. This allows an improvement of the COP of the HP and, therefore, of the energy conversion efficiency. In Spain, a commercial term "thermodynamic solar cell" appears around 2006. From a commercial point of view, it is more socially impactful taking about "solar cells" than "HP", as solar cell is a term associated with positive connotations (ecologic, renewable, etc), which are not used when talking about HPs. However, the reality is that a "thermodynamic solar cell" is a SAHP. Ozgener et al. [8] have done a classification of SAHP according to the literature: (i) SAHPSs for water heating, (ii) SAHPSs with storage (conventional type) for space heating, (iii) SAHPSs with direct expansion for space heating, and (iv) Solar-Assisted Ground Source Heat Pump Greenhouse Heating System (SAGSHPGHS). Ji et al. [9] proposed in 2007 a novel Photo-Voltaic Solar Assisted Heat Pump (PV-SAHP) system capable of providing space cooling-heating and domestic water-heating. The solar panels are actually an assembly of PV cells laminated onto the evaporator-collector plate, allowing the direct solar energy absorption and, therefore, improving the protection of the evaporator from frosting in winter. Through experiments, the maximum COP (10.4) was obtained when the solar irradiance was also the highest. Then, they concluded that PV-SAHP system is better than the conventional HP systems.

- Compressor. Gas Engine Heat Pumps (GEHPs) have the compressor driven by a gas (natural gas, propane or LPG) fuelled internal by a combustion engine instead of electricity.

- Valve. There are two types: reversible (inverter) and irreversible, depending of the type of valve (four or two-way valves).

\subsubsection{Net work input}

HPs require energy (net work, W) for operating, so they can be basically divided into Electricdriven Heat Pumps (EHPs) and the Gas Engine Driven Heat Pump (GEHPs). 


\subsubsection{Cold reservoir}

Directive 2009/28/CE enables HPs to use aerothermal, geothermal or hydrothermal heat. HPs are formally classified as air source, ground source or water source depending on the thermal reservoir they use. But there are hybrid HPs which combine, for example, ground source/air source units, and solar assisted and solar boosted air source and water source units.

\subsubsection{Air-source HPs}

The most common type of HP is the air-source HP. This category includes the air-to-air and air-to-water HPs. The solar energy is stored in the air, so this HP indirectly uses solar energy. They operate using fans to draw air across the evaporator. The inconvenient is their efficiency is influenced by the variation in ambient air temperature. If this temperature drops below $4{ }^{\circ} \mathrm{C}$, ice may appear in the evaporator, so efficiency decreases. The main advantage if compared with Ground Source Heat Pumps (GSHPs) is the relatively low capital cost.

\subsubsection{Ground-source heat pumps (GSHPs)}

GSHPs are also known as Geothermal Heat Pumps (GHPs). Yang et al. [10] classified these systems according to the source where they absorb the energy. This means that the cold reservoir could be the ground, ground water or surface water, and based on the type of reservoir there are basically three categories: (i) Ground-Coupled Heat Pump (GCHP) systems, (ii) Ground Water Heat Pump (GWHP) systems and (iii) Surface Water Heat Pump (SWHP) systems. They may be also classified according the loop: open loop (ground coupled) or closed loop (water source) [8]. The great advantage is the underground temperature remains fairly constant during the year, so this technology offers higher energy efficiency. However, in the case of SWHP the surface water temperature is influenced by weather condition. The pipes are buried in the ground horizontally or vertically. The horizontal system installation is less expensive than vertical one, but it requires much more ground area and it is more influenced by ambient air temperature.

\subsubsection{Water-source heat pumps (WAHPs)}

WAHPs, as the term implies, obtain heat from a large body of water source. As it uses water from the Earth as their energy source, WSHPs are incorporated in ground-source HPs. The classification has been shown before in 2.2.4.2, where SWHP employed a lake loop instead of water wells used in GWHP.

\subsubsection{Hot reservoir}

It is not usual to classify HPs according to the hot reservoir. It is more common to consider the relation between the cold and hot reservoir, which is explained in the next epigraph.

\subsubsection{Cold reservoir-Hot reservoir}

The types of HPs are usually determined by the combination of the heat source and the heat sink (where the heat is absorbed and where the heat is discharged) [11]. The cold reservoir is employed as heat source, and it may be the air, the ground or water. Depending on the nature of the hot reservoir, there are two possibilities: air or water, according to the objective. For example, air-to-water HP transfers heat from ambient air, which is used as cold reservoir, to water for space heating (radiators or an under floor heating system) or for domestic sanitary hot water [12]. On the other hand, air-to-air HP works transferring heat from the air outside to inside the building, where it is distributed by moving air. In the same way there are other systems [13]: ground-to-water, ground-to-air, water-to-water and water-to-air. It is observed 
that this nomenclature is more used in the commercial sector, though it can also be found in scientific papers. In the commercial sphere there may also be found combinations like sunwater and sun-air, when a solar collector is used to obtain the heat [14].

\section{Micro-cogeneration}

Micro-cogeneration, also termed Micro-Combined Heat and Power (MCHP) or residential cogeneration, is a technology that has the ability to produce both useful thermal energy and electricity from a single source. Fuel is used more efficiently (Fig. 3), as a heat exchanger recovers waste heat from the engine and/or exhaust gas to produce hot water or steam [15].

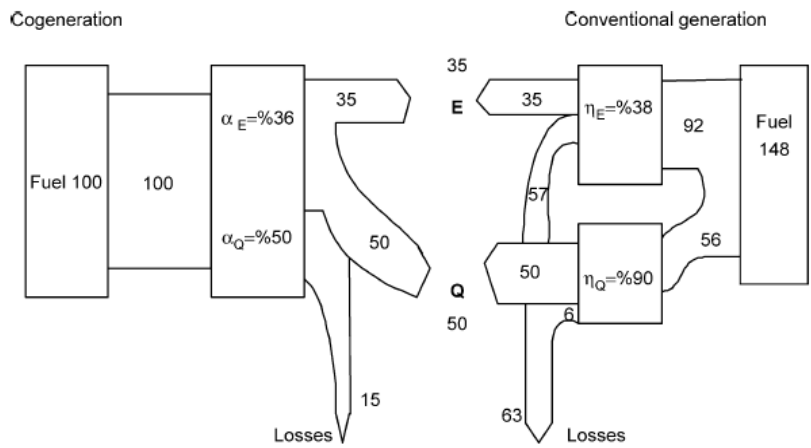
$\alpha_{E}$, part of the energy transformed into electricity in a cogeneration unit.
$\alpha_{\mathrm{Q}}$, part of the energy transformed into usable heat in a cogeneration unit.
$\eta_{\mathrm{E}}$, electrical yield of an electrical power plant (electricity production only).
$\eta_{Q}$, yield of a boiler (heat production only).
E, electricity demand.
Q, heat demand.

Fig. 3. Difference of primary energy consumption required for producing the same amount of heat and power using conventional fossil fuel fired electricity generation and boiler system compared to a cogeneration system [14].

The small-scale implementation $(<10 \mathrm{~kW})$ or cogeneration is a solution that provides all the advantages of cogeneration, as controlled and predictable energy savings and emissions, energetic decentralization, supply security, etc [16].

\subsection{Micro-cogeneration classification}

A variety of types of cogeneration systems are commercially available (Table 1). The choice of the system depends on factors such as the demand of power and thermal energy, the choice of prime mover, capital installation and maintenance, etc. Some systems have been developed for micro-cogeneration, and their actual conditions are shown in Table 2.

Table 1. Cogeneration technologies [17].

\begin{tabular}{ccc}
\hline & Cogeneration Technology & \\
\hline Combined cycle gas turbines & Steam turbine plants & Stirling engines \\
Steam condensing extraction & Gas turbines with recovery & Steam engines \\
turbine & boilers & Fuell cells \\
Internal combustion engines & Microturbines & Organic Ranking cycles \\
\hline
\end{tabular}

Table 2. Status of micro-cogeneration technologies [18].

\begin{tabular}{|c|c|c|c|c|c|c|c|}
\hline Technology & $\begin{array}{c}\eta_{E} \\
(\%)\end{array}$ & $\begin{array}{c}\eta_{\mathrm{Q}} \\
(\%)\end{array}$ & $\begin{array}{c}\eta_{\mathrm{T}} \\
(\%)\end{array}$ & $\begin{array}{l}\text { Minimal } \\
\text { load (\%) }\end{array}$ & $\mathrm{T}\left({ }^{\circ} \mathrm{C}\right)$ & $\begin{array}{l}\text { Noise } \\
(\mathrm{dB})\end{array}$ & Fuel \\
\hline Gas turbine & $15-35$ & $40-59$ & $60-85$ & 75 & $450-800$ & $62-75$ & Natural gas \\
\hline $\begin{array}{l}\text { Alternative internal } \\
\text { combustion engines }\end{array}$ & $25-45$ & $40-60$ & $70-85$ & 50 & $300-600$ & $52-56$ & $\begin{array}{l}\text { Gas, diesel, } \\
\text { biofuel }\end{array}$ \\
\hline Stirling engines & $25-50$ & $40-60$ & $70-90$ & 50 & $300-600$ & 56 & All \\
\hline Fuel cells & $35-55$ & $40-60$ & $70-90$ & No limit & $250-550$ & Low & $\mathrm{H}_{2}$ \\
\hline
\end{tabular}

$\eta_{\mathrm{E}}$ : electric yield; $\eta_{\mathrm{Q}}$ : thermal yield; $\eta_{\mathrm{T}}$ : total yield; $\mathrm{T}$ : temperature 


\subsubsection{Reciprocating internal combustion engine}

Reciprocating internal combustion engines are classified by their method of ignition: compression ignition (Diesel) engines and spark ignition (Otto) engines. Spark ignition engines are used typically for micro-cogeneration due to their heat recovery system producing up to $160^{\circ} \mathrm{C}$ hot water compared to diesel engines, where the temperature is often lower. Their efficiencies range from 25 to $45 \%$. The main advantage is that their technology is mature and well-understood. It can be designed for different fuels but it needs frequent maintenance. On the other hand, as this technology burns fossil fuel there are emissions of pollutants such as oxides of nitrogen (NOx), carbon monoxide (CO), and volatile organic compounds (VOCs — unburned, non-methane hydrocarbons).

\subsubsection{Micro-turbines}

The basic components are the compressor, turbine generator and the recuperator. The thermodynamic process involves the pressurization of intake air by the compressor. The compressed air and a suitable fuel are mixed and ignited in a combustion chamber. The resulting hot combustion gas expands turning the turbine, which drives the compressor and provides power by rotating the compressor turbine shaft. With the recuperator, the hot exhaust gas helps pre-heat the air as it passes from the compressor to the combustion chamber. This increases the efficiency of the system. At first, micro-cogeneration competes with HP technologies but actually they may complement each other. For example, the remaining electricity generated from micro-cogeneration system is to meet a portion of the heating and cooling needs through the use of HPs. Ehyaei et al. [19] show how the excess electricity generated by the micro-turbines can to be used in a HP. This technology offers a high-grade of waste heat and other advantages such as a compact size, low weight, low maintenance requirements and lower noise. However, in the lower power ranges, reciprocating internal combustion engines have higher efficiency. It also produces pollutants (but in minor amount than the reciprocating internal combustion engine) as $\mathrm{NOx}, \mathrm{CO}$ and unburnt hydrocarbons, and insignificant amounts of $\mathrm{SO}_{2}$.

\subsubsection{Fuel cells}

Fuel cell technology is an emerging technology with a potential for cogeneration applications and is currently being developed for use in residential applications (3-10 kW). It can run independently or in parallel to a power grid [20]. The electrochemical reaction of hydrogen and oxygen in the presence of an electrolyte produces electricity without combustion and mechanical work. Water and heat are the only byproducts. Fuel cells normally run with hydrogen but can also be used with natural gas, propane or other fuels by external or internal reforming or through the electrolysis of water too. The advantages include low noise level, potential for low maintenance, low emissions and potential to achieve an overall efficiency of 85-90\% even with small units. The fuel cell is the most promising technology and gradually becomes available, but it still has a problem with its high cost and relatively short lifetime.

\subsubsection{Stirling engine}

Stirling engine is an external combustion engine operated on the Stirling cycle, not totally developed yet. The cycle consists on four internally reversible processes in series: isothermal compression at constant temperature, constant-volume heating, isothermal expansion at constant temperature, and constant-volume cooling. The Stirling cycle engine can use different types of renewable sources of energy including biomass, solar and geothermal energy [21], so it offers opportunities for high efficiency with reduced emissions. It can be operated with a wide variety of fuels, the maintenance may be low and the life is usually long. 
The major disadvantage is its high cost. Stirling engines can be classified according to their arrangement: the Alpha, Beta and the Gamma. This technology and fuel cell for cogeneration systems seem promising for residential and small-scale commercial applications.

\section{Conclusions}

HPs offer an energy-efficient and economical alternative to HVAC (Heating, Ventilating and Air Conditioning) systems for residential applications. According to recently published European legislation, HP can be considered as a renewable energy technology, since it is based on the essential feature of these unlimited sources, such as the water, air and ground. The micro-cogeneration is an emerging technology that produces useful thermal energy and electricity from a single resource of fuel, in the same place of consumption or close to it. Even though HP and micro-cogeneration technologies require less than conventional devices, they do require energy, usually obtained from the power distribution system where fuel is mainly converted to electrical energy at power plants and the waste heat is discharged to the environment. So it is not exactly correct to state that they are renewable energy technologies. For example in Spain, renewable companies offer geothermic energy for building, but generally is a "false" geothermal energy because it uses solar energy absorbed from the ground surface. Real geothermal energy uses the thermal energy stored into the Earth. Nevertheless, they are really efficient technologies that could involve a great change in the current power distribution system of centralized generation and could give way to distributed generation. This will minimize energy losses due to electrical transmission and distribution system. These will allow having fuel conversion systems close to consumption points, and energy efficiency could become higher. In addition, the waste heat of fuel combustion can be recovered by approximately $80 \%$.

Considering the electrically driven HP technology within power distribution system of distributed generation and renewable supply like photovoltaic solar energy will be a great choice. This may be an alternative for Europe since their solar energy potential [22], especially of Southern Europe.

According to the Spanish regulation, the technologies presented are a good alternative. Moreover, these technologies provide a chance to change the current power distribution system (based on large electrical generation plants far from consumption points) by becoming a generation system where the electricity is generated and consumed in the same site or nearby. The distributed generation has the potential to reduce losses due to electrical transmission and distribution inefficiencies and to alleviate utility peak demand problems.

The possibilities of these technologies that use renewable energy suppose a great chance. The CHP (Combined Heat and Power) plants can be integrated with other fuels/technologies such as biomass, geothermal energy or solar collectors. But this makes no sense outside a bioclimatic construction field.

\section{References}

[1] EU, Directive 2010/31/EU on the energy performance of buildings, Official Journal of the European Communities L153, 2010, pp. 13-35.

[2] N. Pardo, A. Montero, J. Martos, J.F. Urchueguía, Optimization of hybrid - ground coupled and air source - heat pump systems in combination with thermal storage, Applied Thermal Engineering, 30, 2010, pp. 1073-1077. 
[3] EU, Directive 2002/91/EC on the energy performance of buildings, Journal of the European Communities L1, 2002, pp. 65-71.

[4] EU, Directive 2009/28/EC on the promotion of the use of energy from renewable sources, Official Journal of the European Communities L140, 2009, pp. 16-62.

[5] L. Aye, W.W.S. Charters, Electrical and engine driven heat pumps for effective utilisation of renewable energy resources, Applied thermal engineering, 23, 2003, pp. 1295-1300.

[6] M.J. Moran, H.N. Shapiro, Fundamentals of engineering thermodynamics, Wiley, 5th edition, 2006.

[7] L. Chen, N. Ni, C. Wu, F. Sun, Performance analysis of a closed regenerated Brayton heat pump with internal irreversibilities, International Journal of Energy Research, 23, 1999, pp. 1039-1050.

[8] O. Ozgener, A. Hepbasli, A review on the energy and exergy analysis of solar assisted heat pump systems, Renewable \& Sustainable Energy Reviews, 11, 2007, pp. 482-496.

[9] J. Ji, G. Pei, T. Chow, K. Liu, H. He, J. Lu, C. Han, Experimental study of photovoltaic solar assisted heat pump system, Solar energy, 82, 2008, pp. 43-52.

[10]H. Yang, P. Cui, Z. Fang, Vertical-borehole ground-coupled heat pumps: A review of models and systems, Applied energy, 87, 2010, pp.16-27.

[11]HPs as a renewable energy (in Spanish), El instalador magazine, 458, 2008, pp. 5-8.

[12] Toshiba, Air to water heat pump system, (available at http://www.toshiba-aircon.jp).

[13]A. Pither, N. Doyle, UK Heat Pump Study, 2005 (available at Energy Efficiency Partnership for Homes, http://www.eeph.org.uk).

[14]H.I. Onovwiona, V.I. Ugursal, Residential cogeneration systems: review of the current technology, Renewable and sustainable energy reviews, 10, 2006, pp. 389-431.

[15] M. Goodell, About the Renewable Energy Institute, Climate Science \& America's Clear and Present Danger, 2010 (available at http://cogeneration.net/).

[16]D. Arzoz del Val, Energy saving in buildings by small-scale cogeneration (in Spanish), El instalador magazine, 466, 2009, pp. 70-72.

[17]European Commission, Reference Document on Best Available Techniques for Energy Efficiency, Institute for Prospective Technological Studies (IPTS), 2009.

[18]Energylab, Electricity micro-cogeneration: concepts, typology and results (in Spanish), Plenary Conference on the Electricity micro-cogeneration Seminar, 2010.

[19] M.A. Ehyaei, M.N. Bahadori, Selection of micro turbines to meet electrical and thermal energy needs of residential buildings in Iran, Energy and Buildings, 39, 2007, pp. 1227-1234.

[20]US Fuel Cell Council, www.usfcc.com.

[21]D. Scarpete, K. Uzuneanu, N. Badea, Stirling Engine in Residential Systems Based on Renewable Energy, (available at http://www.wseas.us).

[22]M. Šúri, T.A. Huld, E.D. Dunlop, H.A. Ossenbrink, Potential of solar electricity generation in the European Union member states and candidate countries, Solar Energy, 81, 2007, pp. 1295-1305(available at http://re.jrc.ec.europa.eu/pvgis/). 